\title{
Role of ammonia in the pathogenesis of the gastritis, hypergastrinaemia, and hyperpepsinogenaemia I caused by Helicobacter pylori infection
}

\author{
A M El Nujumi, P A Rowe, S Dahill, C A Dorrian, W D Neithercut, K E L McColl
}

\begin{abstract}
Studies were performed in patients with and without renal failure to investigate the role of bacterial ammonia production in the pathogenesis of the mucosal abnormalities caused by Helicobacter pylori. The high rate of $H$ pylori ammonia production in uraemic patients should accentuate any ammonia induced effects. The median (range) gastric juice ammonium concentration in the $\boldsymbol{H}$ pylori positive patients with renal failure was 19 mmol// (1I-43) compared with $5 \mathrm{mmol} / \mathrm{l}$ (1-11) in the $H$ pylori positive patients without renal failure $(p<0.005)$. In the $H$ pylori negative patients the values were $3 \mathrm{mmol} / \mathrm{l}(0.5-11)$ and $0.7 \mathrm{mmo} / \mathrm{l}(0.1-1.4)$ respectively in the patients with and without renal failure $(p<0.01)$. Despite the much higher ammonia production in the $\boldsymbol{H}$ pylori positive uraemic patients, the nature and severity of their gastritis was the same as that in the $H$ pylori positive non-uraemic patients. The median (range) fasting serum gastrin concentration was raised in the uraemic patients compared with the non-uraemic patients but was similar in the uraemic patients with (95 $\mathrm{pmol} / \mathrm{l}$ (52-333)) or without (114 pmol/ (47-533)) H pylori infection. The median (range) serum pepsinogen I concentration was also high in the uraemic compared with the non-uraemic patients and was significantly higher in uraemic patients with $H$ pylori $(352 \mathrm{ng} / \mathrm{ml}$, range $280-653)$ than in those without $H$ pylori infection $(165 \mathrm{ng} / \mathrm{ml}$, range $86-337)(\mathrm{p}<0.01)$. These findings indicate that the gastritis and hypergastrinaemia associated with $H$ pylori infection are not the result of mucosal damage induced by the organism's ammonia production.
\end{abstract}

(Gut 1992; 33: 1612-1616)

University Departments of Medicine and Therapeutics,

Pathological

Biochemistry, and

Pathology, Western

Infirmary, Glasgow

A M EI Nujumi

P A Rowe

S Dahill

C A Dorrian

W D Neithercut

K E L McColl

Correspondence to:

Dr K E L McColl, University Department of Medicine and Therapeutics, Western Infirmary, Glasgow G11 6NT.

Accepted for publication

31 May 1992
It is now generally acknowledged that Helicobacter pylori infection is the major cause of antral gastritis.' The bacterium, however, does not penetrate the gastric epithelium and the mechanism by which it induces inflammation of the underlying mucosa is unknown. The organism has very high urease activity' and it has been suggested that the production of high concentrations of ammonia at the epithelial surface could cause mucosal damage. ${ }^{3}$ Though the acidic gastric juice will rapidly convert ammonia to less toxic ammonium ions, the high $\mathrm{pH}$ at the site of ammonia production underneath the mucus layer could allow it to remain in its unionised noxious state. ${ }^{+5}$ It has also been postulated that ammonia produced by $H$ pylori predisposes to mucosal damage by denaturing the structure of the protective mucus layer. ${ }^{6}$

$H$ pylori infection has also been shown to increase the serum concentrations of gastrin ${ }^{7-12}$ and pepsinogen $\mathrm{I}^{7{ }^{13}}$ Levi et al proposed that the hypergastrinaemia was related to bacterial ammonia production which raised the antral surface $\mathrm{pH},{ }^{8}$ but studies from our own group do not support this. ${ }^{1+18}$

To investigate the role of ammonia in the histological and biochemical changes that accompany $H$ pylor infection, we have examined patients with chronic renal failure. The high intragastric urea concentrations in these patients greatly increase $H$ pylori ammonia production which should accentuate any ammonia related effects.

\section{Patients and methods}

Gastric juice ammonium concentration, antral histology, and serum concentrations of gastrin and pepsinogen I were examined in nine $H$ pylori positive and nine $H$ pylori negative uraemic patients. These results were compared with those from age and sex matched control patients with normal renal function with $(n=9)$ and without $(\mathrm{n}=9) H$ pylori infection. Each of the patients examined had been referred for upper gastrointestinal endoscopy to investigate dyspeptic symptoms. None was receiving antibiotics or had taken acid inhibitory agents within the previous week. In addition, none of the patients had been treated with bismuth preparations or with immunosuppressive therapy.

The median ages of the uraemic patients were 51 years (range 34-73) in those who were $H$ pylori positive and 49 years (range 27-67) in those who were $H$ pylori negative. Three of the $H$ pylori positive patients were on maintenance haemodialysis, four on continuous ambulatory peritoneal dialysis, and two had not yet begun dialysis. One of the $H$ pylori negative patients was on maintenance haemodialysis and eight were on continuous ambulatory peritoneal dialysis. The median duration of dialysis was similar in the $H$ pylori positive (15 months, range $0-100)$ and negative (20.5 months, range 0-142) patients.

All patients were examined between 0900 hours and 1100 hours after an overnight fast. Upper gastrointestinal endoscopy was performed after a venous blood sample had been taken for determination of serum concentrations of urea, gastrin, and pepsinogen I. Immediately after passing the instrument, $10 \mathrm{ml}$ of gastric juice were collected by means of a trap in the suction line. After inspection of the upper 
gastrointestinal tract, two biopsy specimens were taken from the greater curvature of the antrum, $2 \mathrm{~cm}$ from the pylorus.

The $H$ pylori status of patients and controls was determined by microscopy of antral biopsy for Helicobacter like organisms, rapid urease slide test (CLO test) of antral biopsy, ${ }^{14}$ and ${ }^{1+} \mathrm{C}$-urea breath test. These tests have been shown to be reliable in detecting $H$ pylori infection in patients with and without renal failure.

\section{ANALYSES}

In the patients with chronic renal failure the $\mathrm{pH}$ of the gastric juice was determined using a combined glass electrode (Radiometer ETS 822) before storage at $-20^{\circ} \mathrm{C}$. Gastric juice urea and ammonium concentrations were determined in all subjects. For this the samples were thawed and centrifuged at $3000 \mathrm{~g}$ for 10 minutes to remove the mucus. The concentration of ammonium was measured in the supernatant after dilution in $0 \cdot 2 \mathrm{M}$ phosphate buffer $\mathrm{pH} 7 \cdot 4$, using an enzymatic method (Sigma, Dorset, UK) adapted for the Cobas Bio (Roche, Welwyn Garden City, UK) as previously described." ${ }^{21}$

The antral biopsy specimens were fixed in formalin and processed routinely. Paraffin sections were cut at three levels and stained with haematoxylin and eosin. An extra section from level two was stained with Cresyl fast violet for detection of $H$ pylori. ${ }^{22}$ They were examined by a single pathologist (SD) who was unaware of the patients' clinical details. The severity of antral gastritis was scored using the method of Rauws et $a l,{ }^{23}$ which we have found to be a sensitive method for assessing the severity of $H$ pyloriinduced gastritis. ${ }^{91621}$ Chronic inflammatory infiltrate in the lamina propria was scored as 0 , 1 , or 2 ; lamina propria polymorph infiltrate as $0,1,2$, or 3 ; intraepithelial polymorph infiltrate

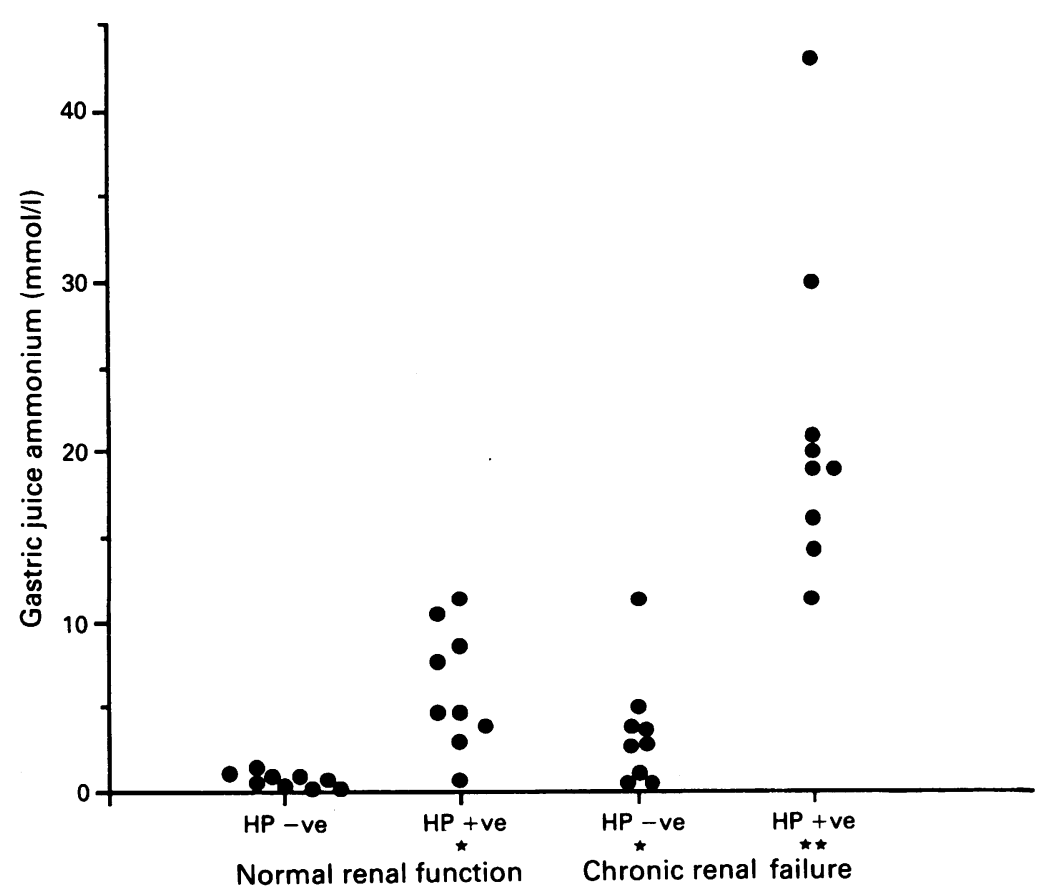

Figure 1: Effect of uraemia and Helicobacter pylori $(H P)$ status on intragastric ammonium concentrations. ${ }^{\star}$ Indicates higher than $\mathrm{H}$ pylori - ve non-uraemic patients at $p<0.02$. $\star \star$ Indicates higher than the $\mathrm{H}$ pylori $+v e$ non-uraemic patients at $p<0.005$. as $0,1,2$, or 3 ; and mucosal erosions as 0,1 , or 2 . The scores for these individual components of $H$ pylori related gastritis are then added to give a cumulative gastritis score ranging from 0-10.

The intraobserver variation in the scoring of the severity of the gastritis was assessed. This was performed by randomly selecting 15 slides scored by the pathologist (SD) at least one year earlier and having him rescore them unaware that he had previously examined them. The mean cumulative gastritis score for the group of 15 slides was $3 \cdot 2$ (range $0-6$ ) when first scored compared with $3 \cdot 3$ (range $0-8$ ) when rescored. The mean absolute difference in the cumulative gastritis score between the two assessments was 0.66 (range 0-2) and the coefficient of variation was $21 \%$. This indicates that our pathologist would have a greater than $95 \%$ chance of detecting a difference in mean cumulative gastritis score of 1 when comparing two groups of nine subjects.

The serum gastrin concentration was determined by radioimmunoassay using antibody R98. ${ }^{2+}$ This detects both G17 and G34 and uses G17 as standard. Serum pepsinogen I was measured using commercial radioimmunoassay kits obtained from Incstar Ltd (Berkshire).

The statistical significance of differences between groups was assessed by the MannWhitney U test.

The study was approved by the Western Infirmary Ethical Committee and all patients gave written, informed consent.

\section{Results}

The serum urea concentration was raised to a similar extent in the renal failure patients with (median $20 \mathrm{mmol} / \mathrm{l}$, range $12-31$ ) or without (23, 11-32) $H$ pylori infection (normal range $2 \cdot 5-7 \cdot 5$ $\mathrm{mmol} / \mathrm{l})$.

The median (range) gastric juice ammonium concentration in the $H$ pylori positive uraemic patients was $19 \mathrm{mmol} / \mathrm{l}(11-43)$ which was approximately four times greater than that in the $H$ pylori positive non-uraemic patients (5, range $1-11)(p<0.005)$ (Fig 1). Gastric juice ammonium concentrations were similar in the $H$ pylori negative uraemic patients (median 3, range $0.5-11 \mathrm{mmol} / \mathrm{l}$ ) and $H$ pylori positive nonuraemic patients $(5$, range $1-11)(\mathrm{p}=0 \cdot 2)$, and both were significantly higher than the values for the $H$ pylori negative non-uraemic patients $(0 \cdot 7$, range $0 \cdot 1-1 \cdot 4)(\mathrm{p}<0.02$ for each). Intragastric pH was similar in the $H$ pylori positive and negative uraemic patients, with a median value of 3.0 (range $1 \cdot 0-7 \cdot 1$ ) in the former and $2 \cdot 1$ $(1 \cdot 2-6 \cdot 6)$ in the latter.

In spite of the marked difference in intragastric ammonium concentration, the severity of histological gastritis was similar in the $H$ pylori positive patients with (median cumulative gastritis score $=5$, range 3-6) or without $(5$, range 3-7) renal failure (Fig 2). Combining the $H$ pylori positive patients with and without renal failure provided a wide range of gastric juice ammonium concentrations $(1-43 \mathrm{mmol} / \mathrm{l})$ but there was no correlation between this and the severity of the $H$ pylori related antral gastritis (Table). In spite of the $H$ pylori negative uraemic patients having 


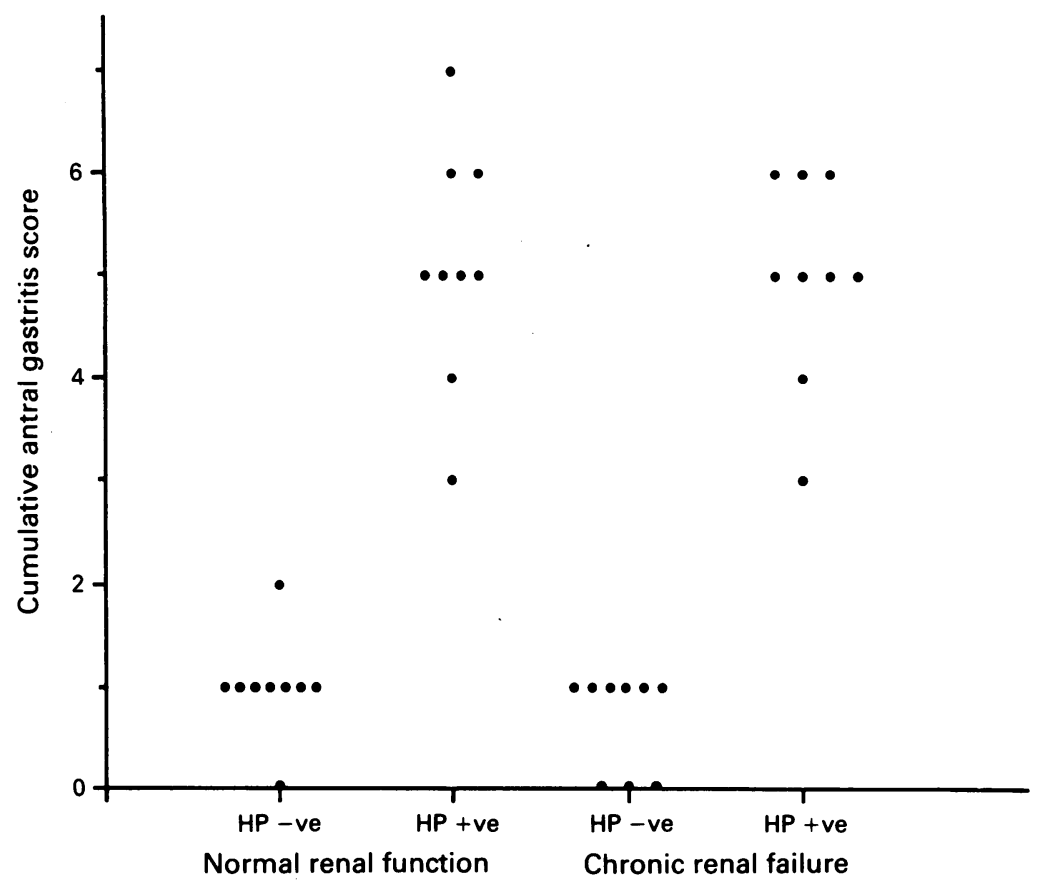

Figure 2: Cumulative antral gastritis scores in patients with and without chronic renal failure and of different Helicobacter pylori $(H P)$ status.

intragastric ammonium concentrations similar to the $H$ pylori positive non-uraemic patients, the former had cumulative gastritis scores of 1 or less which were equivalent to those in the $H$ pylori negative patients with normal renal function.

There was no difference in the endoscopic appearance of the upper gastrointestinal tract in the renal failure patients with and without $H$ pylori infection. Of the nine $H$ pylori positive uraemic patients, two had oesophagitis, two had scattered petechiae in the stomach and duodenum, and one had erosive duodenitis. Of the nine $H$ pylori negative uraemic patients, two had oesophagitis and one had scattered petechiae in stomach and duodenum. Endoscopy in the nine $H$ pylori positive non-uraemic patients showed oesophagitis in one patient and active duodenal ulcer in another. In the nine $H$ pylori negative non-uraemic patients, one had erosive duodenitis and another a deformed duodenum.

Gastric juice ammonium concentrations and antral gastritis scores in the Helicobacter pylori positive subjects with $(+)$ and without $(-)$ chronic renal failure. They are listed in descending order of gastric juice ammonium concentration

\begin{tabular}{|c|c|c|c|c|c|c|}
\hline $\begin{array}{l}\text { Gastric juice } \\
\text { ammonium } \\
\text { (mmol/l) }\end{array}$ & $\begin{array}{l}\text { Chronic } \\
\text { renal } \\
\text { failure }\end{array}$ & $\begin{array}{l}\text { Lamina } \\
\text { propria } \\
\text { chronic } \\
\text { infiltrate score } \\
(0-2)\end{array}$ & $\begin{array}{l}\text { Intra- } \\
\text { epithelial } \\
\text { polymorph } \\
\text { infiltrate score } \\
(0-3)\end{array}$ & $\begin{array}{l}\text { Lamina } \\
\text { propria } \\
\text { polymorph } \\
\text { infiltrate score } \\
(0-3)\end{array}$ & $\begin{array}{l}\text { Epithelial } \\
\text { erosions score } \\
(0-2)\end{array}$ & $\begin{array}{l}\text { Cumulative } \\
\text { gastritis score } \\
(0-10)\end{array}$ \\
\hline $\begin{array}{r}43 \\
30 \\
21 \\
20 \\
19 \\
19 \\
16 \\
14 \\
11 \\
11 \\
10 \\
8 \\
7 \\
5 \\
5 \\
4 \\
3 \\
1\end{array}$ & $\begin{array}{l}+ \\
+ \\
+ \\
+ \\
+ \\
+ \\
+ \\
+ \\
+ \\
- \\
- \\
- \\
- \\
- \\
- \\
- \\
- \\
-\end{array}$ & $\begin{array}{l}2 \\
2 \\
2 \\
2 \\
2 \\
2 \\
1 \\
2 \\
1 \\
2 \\
2 \\
2 \\
2 \\
2 \\
2 \\
2 \\
2 \\
2\end{array}$ & $\begin{array}{l}1 \\
1 \\
2 \\
2 \\
2 \\
2 \\
1 \\
2 \\
1 \\
2 \\
2 \\
1 \\
0 \\
1 \\
1 \\
1 \\
2 \\
2\end{array}$ & $\begin{array}{l}1 \\
2 \\
1 \\
2 \\
1 \\
2 \\
1 \\
2 \\
1 \\
1 \\
2 \\
2 \\
1 \\
2 \\
1 \\
2 \\
2 \\
2\end{array}$ & $\begin{array}{l}0 \\
0 \\
0 \\
0 \\
0 \\
0 \\
0 \\
0 \\
2 \\
0 \\
1 \\
0 \\
0 \\
0 \\
0 \\
0 \\
0 \\
0\end{array}$ & $\begin{array}{l}4 \\
5 \\
5 \\
6 \\
5 \\
6 \\
3 \\
6 \\
5 \\
5 \\
7 \\
5 \\
3 \\
5 \\
4 \\
5 \\
6 \\
6\end{array}$ \\
\hline
\end{tabular}

The median serum pepsinogen I concentration (ng/ml) was higher in the $H$ pylori positive uraemic patients (352, range 280-653) than in the $H$ pylori negative uraemic patients $(165$, range 86-337) $(\mathrm{p}<0.01)$ and both these groups had higher values than the non-uraemic patients of corresponding $H$ pylori status $(\mathrm{p}<0.05$ for each) (Fig 3). Serum pepsinogen I values were similar in the non-uraemic patients with (median $=103$, range $40-170)$ or without $(92,35-127)$ $H$ pylori infection $(\mathrm{p}=0 \cdot 3)$. There was no relationship between the serum pepsinogen I concentration and type of renal replacement treatment.

The median serum gastrin concentration ( $\mathrm{pmol} / \mathrm{l})$ in the non-uraemic patients was higher in those with $H$ pylori (17, range 7-24) than in those without the infection (10, range 7-14) $(\mathrm{p}<0.05)$ (Fig 4). Compared with these nonuraemic patients, the gastrin concentrations were noticeably high in the uraemic patients and there was no difference between the latter patients with (median $=95$, range 52-333) or without (114, range 47-533) $H$ pylori infection. There was no relationship between the serum gastrin concentration and type of renal replacement treatment.

\section{Discussion}

This study shows that the gastric juice ammonium concentration is noticeably affected by both uraemia and $H$ pylori infection. The extremely high intragastric ammonium concentration in the renal failure patients with $H$ pylori infection can be explained by the combination of their high gastric juice urea concentration ${ }^{25}$ and the high urease activity of the organism. We have previously shown that the intragastric production of ammonia by $H$ pylori is controlled by the availability of urea in gastric juice. ${ }^{1+}$

The reason for the higher gastric juice ammonium concentration in the $H$ pylori negative uraemic patients than in the $H$ pylori negative non-uraemic patients is not clear. However, a variety of urease producing bacteria are present in the mouth and swallowed in the saliva. ${ }^{21}$ Though such bacteria have lower urease activity than $H$ pylori, they may produce significant amounts of ammonia in the presence of high gastric juice concentrations of urea. In addition, it is possible that the high gastric juice urea concentration encourages the colonisation of the upper gastrointestinal tract by urease positive organisms. We have previously observed that $H$ pylori negative uraemic patients have higher urease activity assessed by the ${ }^{14} \mathrm{C}$-urea breath test than $H$ pylori negative non-uraemic patients. ${ }^{20}$

Some in vitro and experimental animal studies have suggested that the antral gastritis induced by $H$ pylori may be caused by the ammonia produced by the organism's high urease activity. ${ }^{27} 29$ Murakami et al showed that ammonia produced by the administration of urea plus urease to rats can cause microscopic injury to their gastric mucosa. ${ }^{3}$ In vitro studies by Smoot $e$ a $a l$ showed that ammonia produced by $H$ pylori is cytotoxic to cultures of human gastric epithelial cells ${ }^{27}$ and similar studies by $\mathrm{Xu}$ et al 


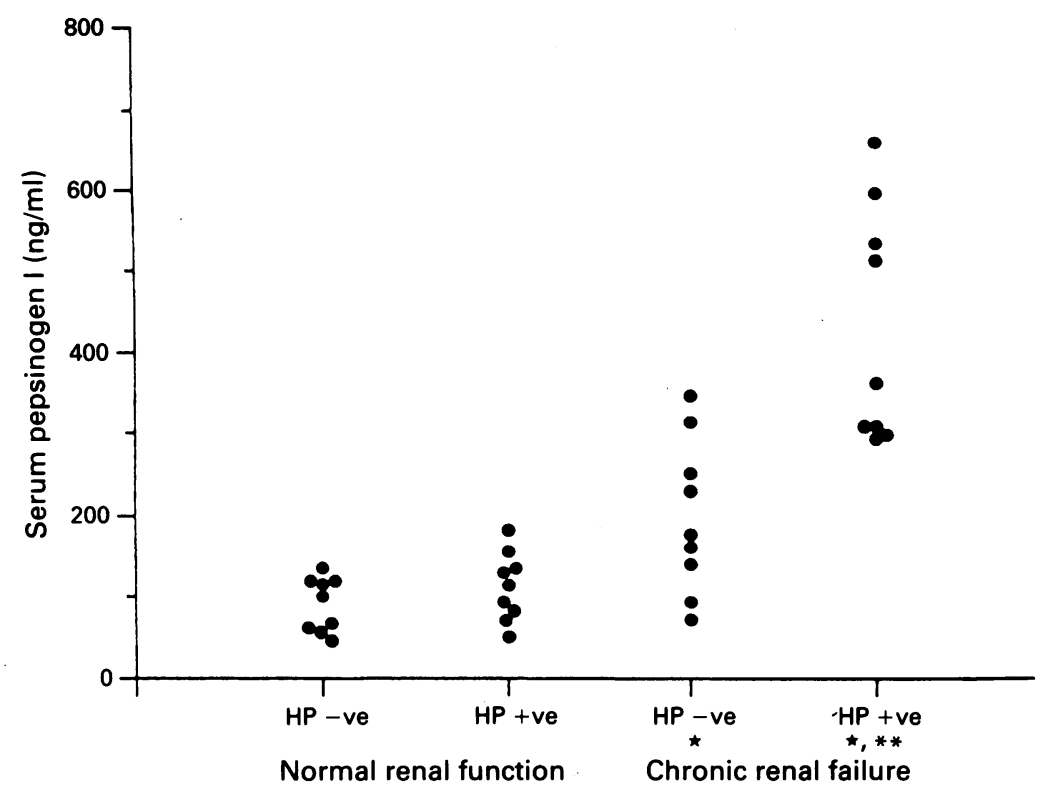

Figure 3: Serum pepsinogen I concentrations in patients with and without chronic renal failure and of different $\mathrm{Helicobacter}$ pylori $(H P)$ status. ${ }^{\star}$ Indicates higher than non-uraemic patient of corresponding $\mathrm{H}$ pylori status at $p<0.05$. ${ }^{\star}$ Indicates higher than $\mathrm{H}$ pylori - ve uraemic patients at $p<0.001$. uraemia enabled us to look at the gastric mucosal damage over a very wide range ( 43 fold) of in vivo ammonia production making it unlikely that any association was missed. The abnormalities related to ammonia administration noted in the earlier in vitro studies and animal models may be explained by the high $\mathrm{pH}$ employed which would have increased the proportion of unionised ammonia.

Triebling et al have recently claimed that ammonia production does play a pathogenic role in the development of $H$ pylori related gastritis in man. ${ }^{30}$ However, this conclusion is not supported by their own data. They measured gastric juice ammonium and the severity of gastritis in five patients with chronic renal failure and $H$ pylori, before and after treatment with ampicillin, and in five uninfected patients with renal failure. A positive correlation was observed between the gastric juice ammonium and severity of gastritis. This correlation, however, can be explained simply by the presence of absence of $H$ pylori in their patient group and does not provide evidence of a causal association between $H$ pylori ammonia production and gastritis. Within their small group of five patients with $H$ pylori, there was no correlation between gastric juice ammonium and severity of gastritis, which is consistent with the findings of our present study in which we examined 18 such patients. Our conclusion that ammonia does not play a pathogenic role in the development of $H$ pylori related gastritis in man is also consistent with the recent ultrastructural studies by Thomsen et al..$^{31}$ They noted that there was no correlation between the location of the organism and the morphological damage to adjacent epithelial cells or the degree of subjacent inflammatory cell infiltrate.

The noticeably high serum pepsinogen I concentration in the patients with chronic renal failure is consistent with previous reports ${ }^{32}$ and can be explained by its impaired renal clearance. ${ }^{33}$ The increase in serum pepsinogen I was particularly marked in the renal failure patients with $H$ pylori, with its concentration being double that in the renal patients without the infection. It has previously been reported that $H$ pylori infection raises serum pepsinogen $\mathrm{I}$ in non-uraemic patients but only by about $25 \% .^{713}$ The fact that $H$ pylori infection raises serum pepsinogen I to a greater extent in uraemic than non-uraemic subjects would be consistent with bacterial ammonia production raising the serum concentration of the zymogen. However, little is known about the mechanism by which pepsinogen I reaches the serum or about the mechanism of its renal excretion. ${ }^{33}$ If it is excreted by a saturable process then in patients with renal failure the same degree of increased delivery of pepsinogen I into the serum could produce a more marked increase in its serum concentration.

As previously reported, the serum gastrin concentration was found to be high in the renal failure patients compared with those with normal renal function. ${ }^{3+37}$ Serum gastrin concentration is also known to be raised in patients with $H$ pylori infection, ${ }^{7-12}$ and this is seen in the nonuraemic patients in the present study. It has been 
suggested that the hypergastrinaemia induced by $H$ pylori is caused by the ammonia produced by its urease raising antral surface $\mathrm{pH}$ and thereby blocking the suppression of gastrin release by luminal acid. ${ }^{8}$ However, we have previously found that neither increasing, ${ }^{1+}$ inhibiting, ${ }^{15}$ nor completely abolishing ${ }^{16} \mathrm{H}$ pylori urease activity in man alters serum gastrin. We have also found that $H$ pylori related hypergastrinaemia cannot be explained by ammonia altering mucosal surface $\mathrm{pH} .{ }^{17}{ }^{18}$ The finding that the gastrin concentration is similar in the $H$ pylori positive and negative uraemic patients, despite the much higher rate of ammonia production in the former, is further evidence against the hypergastrinaemia being due to bacterial ammonia production.

Ala-Kaila et al recently observed that patients with chronic renal failure could be divided into two statistically distinct groups according to their degree of hypergastrinaemia. ${ }^{37}$ The differences in gastrin could not be explained by differences in acid secretion or severity of renal failure and they postulated an unknown mechanism causing enhanced synthesis of gastrin. The present study indicates that $H$ pylori infection is not the unknown factor.

In conclusion, this study shows that the very high rate of $H$ pylori ammonia production in uraemic patients is not associated with more marked gastritis or hypergastrinaemia. These findings support our previous work showing that $H$ pylori release of ammonia is unlikely to be responsible for either the hypergastrinaemia or the gastritis caused by this bacterium.

This work was supported by a grant from the Biomedical Research Committee of the Scottish Home and Health Department and
from the Research Support Group of the Greater Glasgow Health from the Research Support Group of the Greater Glasgow Health
Board. The technical assistance of Mrs Devina Filmore, DepartBoard. The technical assistance of Mrs Devina Filmore, Department of Medicine, Queen's University, Belfast; of Miss Jennifer
Harwood, Department of Pathological Biochemistry, Western Infirmary; and the secretarial assistance of Mrs Dorothy Ronney is gratefully acknowledged.

This work was presented at the 1991 Autumn Meeting of the British Society of Gastroenterology and published in abstract form in Gut.

1 McNulty CAM. Pathogenicity of Campylobacter pylori - a causative factor in gastritis? F Gastroenterol 1989; 24 (supp 160): 3-6

2 Marshall B, Langton S. Urea hydrolysis in patients with Campylobacter pyloridis infection. Lancet 1986; i: 965-6.

3 Murakami M, Yoo JK, Inada M, Miyake T. Effect of ammonia on the gastric mucosa in rats: pathophysiological importance of urease in gastric ulcer disease. $\mathcal{F p n ~} \mathcal{F}$ Pharmacol 1988; 47: of urease

4 Visek WJ. Diet and cell growth modulation by ammonia Am $\mathcal{F}$ Clin Nutr 1978; 31: S216-20.

5 Visek WJ. Some aspects of ammonia toxicity in animal cells. 7 Dairy Sci 1968; 51: 286-95.

6 Sidebotham RL, Baron JH. Hypothesis: Helicobacter pylori, urease, mucus, and gastric ulcer. Lancet 1990; 335: 193-5.

7 Oderda G, Vaira D, Holton J, Ainley C, Altare F, Ansaldi N Amoxycillin plus tinidazole for Campylobacter pylor gastritis in children: assessment by serum IgG antibody, pepsinogen I, and gastrin levels. Lancet 1989; i: $690-2$.

8 Levi S, Beardshall K, Haddad G, Playford R, Ghosh P, Calam . Campylobacter pylori and duodenal ulcers: the gastrin link. Lancet 1989; i: 1167-8.

9 McColl KEL, Fullarton GM, Chittajallu R, El Nujumi AM, Macdonald AMI, Dahill SW, et al. Plasma gastrin, daytime intragastric $\mathrm{pH}$, and nocturnal acid output before and at 1 intragastric $\mathrm{pH}$, and nocturnal acid output before and at and months after eradication of Helicobacter pylori in duodenal
10 Graham DY, Opekum A, Lew GM, Evans DJ, Klein PD, Evans DG. Ablation of exaggerated meal stimulated gastrin release in duodenal ulcer patients after clearance of Helicobacter (Campylobacter) pylori infection. A 7 7 Gastroenterol 1990; 85: 394-8.

11 Smith JTL, Pounder RE, Nwokolo CU, Lanzon-Miller S Evans DG, Graham DY, et al. Inappropriate hypergastrinEvans DG, Graham DY, et al. Inappropriate hypergastrinaemia in asymptomatic healthy subject

12 Chittajallu RS, Ardill JE, McColl KEL. The degree of hypergastrinaemia induced by Helicobacter pylori is the same in duodenal ulcer patients and asymptomatic volunteers. Eur $\mathcal{F}$ Gastroenterol Hepatol 1992; 4: 49-53.

13 Chittajallu RS, Dorrian CA, Ardill JES, McColl KEL. Effect of Helicobacter pylori on serum pepsinogen I and plasma gastrin in duodenal ulcer patients. Scand $\mathcal{F}$ Gastroenterol 1992; 27: 20-5.

14 Chittajallu RS, Neithercut WD, Macdonald AMI, McCol KEL. Effect of increasing Helicobacter pylori ammonia production by urea infusion on plasma gastrin concentraproduction by urea infusion
tions. Gut 1991;32: $21-4$.

15 Nujumi AM El, Dorrian CA, Chittajallu RS, Neithercut WD, McColl KEL. Effect of inhibition of Helicobacter pylori urease activity by acetohydroxamic acid on serum gastrin in duodenal ulcer subjects. Gut 1991; 32: 866-70.

16 Chittajallu RS, Dorrian CA, Neithercut WD, Dahill S, McColl KEL. Is Helicobacter pylori associated hypergastrinaemia due to the bacterium's urease activity or the antral gastritis? Gut 1991; 32: 1286-90.

17 Chittajallu RS, Neithercut WD, Ardill JES, McColl KEL. Helicobacter pylori-related hypergastrinaemia is not due to elevated antral surface $\mathrm{pH}$. Studies with antral alkalinisation. Scand $\mathcal{F}$ Gastroenterol 1992; 27: 218-22.

18 McColl KEL, Nujumi AM El, Dorrian CA, Macdonald AMI, Fullarton GM, Harwood J. Helicobacter pylori and hypergastrinaemia during proton pump inhibitor therapy. Scand $\mathcal{f}$ gastrinaemia during proton
Gastoenterol $1992 ; 27: 93-8$.

19 Marshall BJ, Warren R, Francis GJ, Langton SR, Goodwin $\mathrm{CS}$, Blincow ED. Rapid urease test in the management of Campylobacter pyloridis-associated gastritis. $A m \mathcal{F}$ Gastroenterol 1987; 82: 200-10.

20 Nujumi AM El, Rowe P, Dorrian CA, McColl KEL. Value of ${ }^{1+} \mathrm{C}$-urea breath test to diagnose Helicobacter pylori in uraemic patients. Gut 1991; 32: A1220.

21 Neithercut WD, Milne A, Chittajallu RS, Nujumi AM El, McColl KEL. Detection of Helicobacter pylori infection of the gastric mucosa by measurement of gastric aspirate ammonium and urea concentrations. Gut 1991; 32: 973-6.

22 Burnett RA, Brown IL, Findlay J. Cresyl fast violet staining method for Campylobacter-like organisms. $\mathcal{f}$ Clin Pathol method for Cam

23 Rauws EAJ, Langenberg W, Houthoff HJ, Zanen HC, Tytgat GNJ. Campylobacter pyloridis-associated chronic acute antral gastritis. Gastroenterology 1988; 94: 33-40.

24 Ardill JES. The measurement of gastrin by radioimmunoassay (PhD Thesis). Belfast: Queen's University, 1973.

25 Lieber CS, Lefevre A. Ammonia as a source of gastric hypoacidity in patients with uremia. $\mathcal{F}$ Clin Invest $1959 ; 38$. 1271-7.

26 Bowden GHW, Ellwood DS, Hamilton IR. Microbial ecology of the oral cavity. In: Alexander M, ed. Advances in microbial ecology. Vol 3. New York: Plenum Press, 1979.

27 Smoot DT, Mobley HLT, Chippendale GR, Lewison JF, Resau JH. Helicobacter pylori urease activity is toxic to human gastric epithelial cells. Infect Immun 1990; 58: human

$28 \mathrm{Xu} \mathrm{JK}$, Goodwin CS, Cooper M, Robinson J. Intracellular vacuolisation caused by the urease of $\mathrm{H}$ pylori. $\mathcal{F}$ Infect Dis $1990 ; 161: 1302-4$

29 Hazell SL. Urease and catalase as virulence factors of Helicobacter pylori. In: Menge H, ed. Helicobacter pylori 1990 Berlin: Springer-Verlag, 1991: 3-14.

30 Triebling AJ, Korstein MA, Dlugosz JW, Paronetto F, Lieber C. Severity of Helicobacter-induced gastric injury correlate

with gastric juice ammonia. Dig Dis Sci 1991; 36: 1089-96.

1 Thomsen LL, Gavin JB, Tasman-Jones C. Relation of Helicobacter pylori to the human gastric mucosa in chronic gastritis bacter pylori to the human gastric muco
of the antrum. Gut $1990 ; 31: 1230-6$.

32 Samloff IM, Liebman WM, Panitch NM. Serum group pepsinogens by radioimmunoassay in control subjects and pepsinogens by radioimmunoassay in control subjects and
patients with peptic ulcer. Gastroenterology 1975; 69: 83-90.

33 Waldrum HL, Jorde R, Gunnes P. Renal excretion of, and the effect of, posture on serum group I pepsinogens. Scand $\mathcal{Y}$ Gastroenterol 1982; 17: 253-5.

34 Muto S, Murayama N, Asano Y, Hosado S, Moyata M Hypergastrinaemia and achlorhydria in chronic renal failure. Nephron 1985; 40: 143-8.

35 El-Ghonaimy E, Barsoum R, Soliman M, El-Fikky A Rashwan S, El-Rouby $\mathrm{O}$, et al. Serum gastrin in chronic renal failure: morphological and physiological correlations. Am $\mathcal{F}$ Surg 1981; 141: 334-8.

36 Wesdorp RI, Falcao HA, Banks PB, Martino J, Fisher JE. Gastrin and gastric acid secretion in renal failure. Am $\mathcal{F}$ Surg 1981; 141: 334-8

37 Ala-Kaila A, Kekki M, Paronen I, Poakkalo T. Serum gastrin in chronic renal failure: its relation to acid secretion, G-cell in chronic renal failure: its relation to acid secretion, G-cell
density, and upper gastrointestinal findings. Scand 7 density, and upper gastroin 